\title{
EFEKTIFITAS PENYULUHAN KESEHATAN TERHADAP PENGETAHUAN IBU TENTANG KANKER SERVIKS
}

\section{EFFECTIVENESS OF HEALTH PROMOTION TO MOTHER KNOWLEDGE ABOUT CERVIC CENCER}

\author{
Janu Purwono ${ }^{1}$, Senja Atika sari ${ }^{2}$ \\ Akper Dharma wacana Metro
}

\begin{abstract}
ABSTRAK
Insiden kanker meningkat dari 12,7 juta kasus pada tahun 2008 menjadi 14,1 juta kasus tahun 2012 atau meningkat 12 persen. Jumlah kematian akibat kanker di seluruh dunia pada tahun 2012 ditemukan sebanyak 8,2 juta kematian. Prevalensi penyakit kanker di Indonesia juga cukup tinggi. Banyaknya wanita usia subur yang belum mengikuti program deteksi dini kanker serviks menggunakan metode IVA. Tujuan penelitian adalah mengetahui efektifitas penyuluhan kesehatan terhadap pengetahuan ibu tentang deteksi dini kanker servik menggunakan metode Inspeksi Visual Asam Asetat (IVA). Jenis penelitian adalah studi perbandingan (Comparative study) yang dilaksanakan di Kelurahan Iringmulyo Kec. Metro Timur Kota Metro pada bulan Oktober 2016. Populasi penelitian ini adalah seluruh ibu-ibu di kelurahan iring mulyo yang berjumlah 35 orang. Analisis dengan menggunakan paired sample t-test. Hasil penelitian didapatkan dari 35 responden menunjukkan pengetahuan responden sebelum diberikan penyuluhan sebesar 59,23 sedangkan pengetahuan sesudah dilakukan penyuluhan adalah sebesar 80,77 dan hasil uji $t$-test menunjukkan ( $p$ value $=0,000<0,05)$. Kesimpulan penelitian menunjukkan penyuluhan terbukti efektif meningkatkan pengetahuan tentang deteksi dini menggunakan metode IVA.
\end{abstract}

\section{Kata kunci: Penyuluhan kesehatan, pengetahuan, Kanker servik}

\begin{abstract}
ABSTRACK
The incidence of cancer increased from 12.7 million cases in 2008 to 14.1 million cases in 2012 or an increase of 12 percent. The number of cancer deaths worldwide in 2012 was found to be 8.2 million deaths. The prevalence of cancer in Indonesia is also quite high. The number of women of childbearing age who have not followed the early detection program of cervical cancer using IVA method. The purpose of this research is to know the effectiveness of health counseling to the knowledge of women of childbearing age about early detection of cervical cancer using Visual Acetic Acid Inspection method (IVA). The type of research is a comparative study conducted in Iringmulyo sub district. Metro Timur Kota Metro in October 2016. The population of this study is all mothers in awa mulyo village, amounting to 35 people. Analysis using paired sample t-test. Result of research got from 35 respondents show knowledge of respondent before giving counseling equal to 59,23 while knowledge after counseling is equal to 80,77 and result of t-test show show ( $\mathrm{p}$-value $=0,000<0,05$ ). Research indicates that counseling has proven to be effective in improving knowledge about early detection using IVA method.
\end{abstract}

Keywords: Health education, knowledge, cervical cancer 


\section{PENDAHULUAN}

Pola kejadian penyakit pada saat ini telah mengalami perubahan yang ditandai dengan transisi epidemiologi. Secara garis besar transisi epidemiologi ditandai dengan perubahan pola penyakit dari penyakit menular ke penyakit tidak menular seperti kanker yang juga dapat dipengaruhi oleh gaya hidup tidak sehat. Kanker adalah pertumbuhan sel yang tidak terkendali yang dapat menyerang dan menyebar tubuh. Berdasarkan data Badan Kesehatan Dunia (WHO) tahun 2013, insiden kanker meningkat dari 12,7 juta kasus pada tahun 2008 menjadi 14,1 juta kasus tahun 2012 atau meningkat 12 persen. Jumlah kematian akibat kanker di seluruh dunia pada tahun 2012 ditemukan sebanyak 8,2 juta kematian ${ }^{1}$.

Penyebab utama kematian akibat kanker di seluruh dunia adalah karena kanker payudara dengan hampir 1,7 juta kasus baru didiagnosis pada tahun 2012 yang mewakili sekitar 12\% dari semua kasus kanker baru dan 25\% dari semua kanker pada wanita. Negara dengan kasus kanker payudara tertinggi yaitu Belgia yaitu tercatat sebanyak 111.9/100.000 penduduk, disusul Denmark 105/100.000 penduduk dan Prancis 104.5/100.000 penduduk ${ }^{1}$.

Prevalensi penyakit kanker di Indonesia juga cukup tinggi. Berdasarkan data riset kesehatan dasar tahun 2013, prevalensi tumor kanker Indonesia adalah 1,4 per 1.000 penduduk atau 330.000 orang. Frekuensi kejadian kanker terbanyak terjadi di Yogyakarta yaitu mencapai 4,1/1000 penduduk, tertinggi kedua Jakarta yaitu 1,9/1000 penduduk, proporsi terendah terjadi di Gorontalo yaitu terdapat 0,2/1000 penduduk. Sedangkan untuk Provinsi Lampung terdapat sebesar $0,7 / 1000$ penduduk $^{2}$.

Berdasarkan laporan yang masuk dari 25 RS jumlah penderita kanker yang berkunjung dan dirawat di Rumah Sakit di Provinsi Lampung selama tahun 2014 adalah 383 untuk Kanker Leher Rahim dengan capaian pemeriksaan deteksi dini kanker leher rahim di tahun 2014 adalah sebanyak 7.920 orang $^{3}$.

Kanker leher rahim (kanker serviks) merupakan sebuah tumor ganas yang tumbuh didalam leher rahim yaitu bagian terendah dari rahim yang menempel pada puncak vagina. Penyebab terbesar kanker leher rahim adalah infeksi HPV (Human Pappiloma Virus) yang menular lewat hubungan seksual. Seorang perempuan bisa terinfeksi virus ini pada usia belasan tahun dan baru diketahui mengidap kanker 20-30 tahun kemudian setelah infeksi kanker menyebar (umumnya baru terdeteksi saat seorang perempuan berusia paruh baya, sekitar 40 tahunan $)^{4}$. 
Terjadinya kanker serviks juga dapat yaitu sebanyak 527 orang yang tersebar dipengaruhi oleh berbagai faktor seperti beberapa Puskesmas. Untuk cakupan tertinggi gangguan sistem kekebalan, pemakaian terdapat di Puskesmas Ganjar Agung yaitu kontrasepsi, polusi udara, usia, perilaku tidak sehat seperti merokok, paritas, usia wanita saat menikah, multipatner seks. Salah satu upaya yang dapat dilakukan untuk melakukan pencegahan terhadap terjadinya kanker seviks diantaranya melalui pencegahan primer yaitu suatu pencegahan awal kanker yang utama dengan cara menunda hubungan seksual sampai usia reproduksi sehat, tidak berganti-ganti pasangan, dan menghindari pola hidup tidak sehat. Selain pencegahan primer, juga dilakukan pencegahan sekunder yaitu dengan melakukan deteksi dini kanker serviks 5 .

Berkaitan dengan pencegahan sekunder kanker serviks, pemerintah telah membuat program gerakan deteksi dini kanker leher rahim (serviks) melalui metode inspeksi visual asam asetat (IVA) yang akan dipusatkan di 15 kabupaten/kota dengan target $10 \%$ setiap tahun (121.095 orang) secara serentak ${ }^{6}$.

Berdasarkan data profil Kesehatan Kota Metro tahun 2014 menunjukkan bahwa program deteksi dini kanker serviks menggunakan metode inspeksi visual asam asetat (IVA) sudah berjalan, namun masih sedikitnya masyarakat yang ikut berpartisipasi dalam program tersebut. Cakupan deteksi dini kanker leher rahim menggunakan metode IVA pada tahun 2014 sebanyak 191 orang $(10,1 \%)$ dari 1.891 WUS, dan terendah di Puskesmas Purwosari Metro sebanyak 6 orang, sedangkan untuk wilayah Puskesmas Iring Mulyo Program IVA baru berjalan sehingga belum masuk dalam rekapitulasi Profil Kesehatan Kota Metro ${ }^{7}$.

Banyaknya wanita usia subur yang belum mengikuti program deteksi dini kanker serviks menggunakan metode IVA dapat dipengaruhi oleh sedikitnya informasi yang didapatkan oleh masyarakat tentang IVA. Hal ini sesuai dengan domain perilaku bahwa terbentuknya suatu perilaku baru dimulai pada domain kognitif, dalam arti subjek tahu terlebih dahulu terhadap stimulus yang berupa materi atau objek di luarnya. Kemudian menimbulkan pengetahuan baru pada subjek tersebut, dan selanjutnya menimbulkan respons batin dalam bentuk sikap si subjek terhadap objek yang diketahui itu. Akhirnya rangsangan yakni objek yang telah diketahui dan disadari sepenuhnya akan menimbulkan respon lebih jauh lagi yaitu berupa tindakan/praktik (action) terhadap atau sehubungan dengan stimulus atau objek tadi ${ }^{8}$.

Berdasarkan uraian di atas maka penulis tertarik untuk melakukan penelitian tentang efektifitas penyuluhan kesehatan terhadap pengetahuan wanita usia subur tentang deteksi 
dini kanker servik menggunakan metode Inspeksi Visual Asam Asetat (IVA) di Kelurahan Iringmulyo Kec. Metro Timur Kota Metro

\section{METODE}

Jenis penelitian yang digunakan adalah studi perbandingan (Comparative study). Penelitian ini dilaksanakan di Kelurahan Iringmulyo Kec. Metro Timur Kota Metro pada bulan Oktober 2016. Populasi penelitian ini adalah seluruh ibu-ibu di kelurahan iring mulyo yang berjumlah 35 orang. Pengumpulan data dilakukan dengan wawancara menggunakan quesioner. Pengetahuan deteksi dini Ca. Serviks menggunakan Inspeksi Visual Asam Asetat (IVA) menggunakan instrumen quesioner. Analisis data yang dilakukan adalah univariat dan bivariat dengan uji statistik paired sample t-test. Penyajian data dalam bentuk tabel dan disertai narasi.

\section{HASIL}

Hasil penelitian sebagai berikut:

\section{Tabel 1. Distribusi responden menurut umur dan tingkat pendidikan}

\begin{tabular}{lcc}
\hline \multicolumn{1}{c}{ Variabel } & Jumlah & \% \\
\hline Usia & & \\
$<20$ tahun & 2 & 5.8 \\
$20-35$ tahun & 20 & 57,1 \\
$>35$ tahun & 13 & 37,1 \\
\hline Jumlah & 35 & 100 \\
\hline Tingkat Pendidikan & & \\
Pendidikan tinggi & 5 & 14,3 \\
Tamat SMA & 26 & 74,3
\end{tabular}

\begin{tabular}{lcc} 
Tamat SMP & 3 & 8,6 \\
Tamat SD & 1 & 2,9 \\
\hline Jumlah & 35 & 100 \\
\hline
\end{tabular}

Berdasarkan Tabel di atas, dapat diketahui bahwa dari 35 responden sebagian besar berumur 20-35 tahun $(57,1 \%)$, mayoritas tingkat pendidikan responden adalah $\geq$ SMA yaitu terdapat 26 orang $(74,3 \%)$.

\section{Tabel 2}

Distribusi Skor Rata-rata Pengetahuan Ibu tentang Deteksi Dini Kanker Serviks Menggunakan Metode IVA Sebelum Penyuluhan Kesehatan (Pre-test) di Kelurahan Iringmulyo Kec. Metro Timur

\begin{tabular}{lcccc}
\hline \multicolumn{1}{c}{ Variabel } & Mean & SD & $\begin{array}{c}\text { Minimum- } \\
\text { Maksimum }\end{array}$ & CI; 95\% \\
\hline $\begin{array}{l}\text { Pengetahuan } \\
\text { IBU tentang }\end{array}$ & & & & \\
$\begin{array}{l}\text { IVA } \\
\text { sebelum }\end{array}$ & 59,23 & 15,875 & $33-87$ & $53,78-64,68$ \\
$\begin{array}{l}\text { penyuluhan } \\
\text { (pretest) }\end{array}$ & & & & \\
\hline
\end{tabular}

Berdasarkan tabel 2 dapat dijelaskan bahwa sebelum diberi penyuluhan kesehatan tentang deteksi dini kanker serviks menggunakan metode IVA (pre-test), skor ratarata pengetahuan responden adalah 59,23 dengan standar deviasi 15,875. Skor pengetahuan tertinggi responden yaitu 87 dan terendah adalah 33. Pada confidence interval 95\% diyakini bahwa skor rata-rata pengetahuan responden adalah antara 53,78 sampai dengan 64,68 . 
Tabel 3

Distribusi Skor Rata-rata Pengetahuan Ibu tentang Deteksi Dini Kanker Serviks

Menggunakan Metode IVA Sesudah Penyuluhan Kesehatan (Pre-test) di Kelurahan Iringmulyo Kec. Metro Timur

\begin{tabular}{lcccc}
\hline \multicolumn{1}{c}{ Variabel } & Mean & SD & $\begin{array}{c}\text { Minimum- } \\
\text { Maksimum }\end{array}$ & $\begin{array}{c}\text { CI; } \\
\text { 95\% }\end{array}$ \\
\hline $\begin{array}{l}\text { Pengetahuan } \\
\text { IBU tentang }\end{array}$ & & & \\
$\begin{array}{l}\text { IVA sesudah } \\
\text { Penyuluhan }\end{array}$ & 80,77 & 11,489 & $60-100$ & $76,82-$ \\
\begin{tabular}{l} 
(Post-test) \\
\hline
\end{tabular} & & & 84,72 \\
\hline
\end{tabular}

Berdasarkan tabel di atas, dapat dijelaskan bahwa sesudah diberi penyuluhan kesehatan tentang IVA (post-test), skor rata-rata pengetahuan responden adalah 80,77 dengan standar deviasi 11,489. Skor tertinggi responden yaitu 100 dan terendah adalah 60. Pada confidence interval $95 \%$ diyakini bahwa skor rata-rata pengetahuan responden sesudah diberi penyuluhan adalah antara 76,82 sampai dengan 84,72 .

\section{Tabel 4}

Efektivitas Penyuluhan Kesehatan terhadap Pengetahuan Ibu tentang Deteksi Dini Kanker Serviks Menggunakan Metode IVA di Kelurahan Iringmulyo Kec. Metro Timur

\begin{tabular}{|c|c|c|c|c|c|}
\hline Variabel & Mean & $S D$ & $S E$ & $\begin{array}{c}\text { Mean } \\
\text { Differen }\end{array}$ & p-value \\
\hline $\begin{array}{ll}\text { Penget } & \text { Sebelum } \\
\text { ahuan } & \text { penyuluhan } \\
\text { ibu } & \text { (pre-test) }\end{array}$ & 59,2 & 15,8 & 2,6 & & \\
\hline $\begin{array}{ll}\text { tentang } & \text { Sesudah } \\
\text { deteksi } & \text { penyuluhan } \\
\text { dini } & \text { (post-test) }\end{array}$ & & & & 21,543 & 0.000 \\
\hline $\begin{array}{l}\text { mengg } \\
\text { unakan } \\
\text { metode } \\
\text { IVA }\end{array}$ & 80,7 & 11,4 & 1,9 & & \\
\hline
\end{tabular}

Berdasarkan tabel 3 di atas dapat diketahui bahwa pada hasil analisis dengan menggunakan paired sample t-test diperoleh skor rata-rata pengetahuan responden sebelum penyuluhan kesehatan sebesar 59,23 dengan standar deviasi 15,875 dan sesudah penyuluhan sebesar 80,77 dengan standar deviasi 11,489. Pada hasil uji statistik didapatkan nilai $p$-value $=0,000<\alpha$ 0,05, maka dapat disimpulkan bahwa terdapat perbedaan skor rata-rata pengetahuan sebelum dan sesudah penyuluhan, dengan demikian tidak ada alasan untuk menolak $\mathrm{Ha}$ artinya secara statistik terbukti ada pengaruh penyuluhan kesehatan terhadap pengetahuan IBU tentang deteksi dini kanker serviks menggunakan metode IVA.

\section{PEMBAHASAN}

Pengetahuan adalah hasil penginderaan manusia, atau hasil tahu seseorang terhadap objek melalui indera yang dimilikinya (mata, hidung, telinga, dan sebagainya). Suatu perbuatan yang didasari oleh pengetahuan akan lebih langgeng daripada perbuatan yang tidak didasari oleh pengetahuan. Orang yang mengadopsi perbuatan dalam diri seseorang tersebut akan terjadi proses kesadaran (Awareness) dimana orang tersebut menyadari dalam arti mengetahui terlebih dahulu terhadap obyek (stimulus), merasa tertarik (Interest) 
terhadap stimulus atau obyek tertentu. dilakukan, secara perseorangan maupun secara Disini sikap subyek sudah mulai timbul, kelompok dan meminta pertolongan bila perlu ${ }^{10}$. menimbang-nimbang (evaluation) terhadap baik dan tidaknya terhadap stimulus tersebut bagi dirinya. Hal ini berarti sikap responden sudah tidak baik lagi, Trial, dimana subyek mulai melakukan sesuatu sesuai dengan apa yang dikehendaki oleh stimulus, dan adopsi (adoption), dimana subyek telah berprilaku baru sesuai dengan pengetahuan, kesadaran dan sikapnya terhadap stimulus ${ }^{8}$.

Sebagai salah satu langkah untuk meningkatkan pengetahuan masyarakat tentang kesehatan, sampai saat ini tenaga kesehatan masih menggunakan metode penyuluhan karena metode ini jika diterapkan menggunakan bahasa yang mudah dimengerti atau tidak terlalu sulit untuk dimengerti oleh sasaran, dan dalam penyampaian materi disertai media untuk mempermudah pemahaman dan untuk menarik perhatian sasaran seperti melalui poster-poster maupun leaflet telah banyak terbukti mampu meningkatkan pengetahuan masyarakat tentang berbagai masalah kesehatan ${ }^{9}$.

Penyuluhan kesehatan adalah gabungan berbagai kegiatan dan kesempatan yang berlandaskan prinsip-prinsip belajar untuk mencapai suatu keadaan, dimana individu, keluarga, kelompok atau masyarakat secara keseluruhan ingin hidup sehat, tahu bagaimana caranya dan melakukan apa yang bisa

Berdasarkan hasil pengolahan data dapat diketahui bahwa sebelum diberi penyuluhan kesehatan tentang deteksi dini kanker serviks menggunakan metode IVA (pre-test), skor ratarata pengetahuan responden adalah 59,23 dengan standar deviasi 15,875. Skor pengetahuan tertinggi responden yaitu 87 dan terendah adalah 33. Pada confidence interval 95\% diyakini bahwa skor rata-rata pengetahuan responden adalah antara 53,78 sampai dengan 64,68 .

Pengetahuan ibu tentang deteksi dini kanker serviks menggunakan metode IVA sebelum dilakukan penyuluhan skor tertinggi adalah 87 terendah 33 dengan skor rata-rata 59,23. Dari data tersebut nampak bahwa skor rata-rata responden masih rendah dan perlu ditingkatkan.

Hasil pengolahan data diketahui bahwa sesudah diberi penyuluhan kesehatan tentang IVA (post-test), skor rata-rata pengetahuan responden adalah 80,77 dengan standar deviasi 11,489. Skor tertinggi responden yaitu 100 dan terendah adalah 60. Pada confidence interval 95\% diyakini bahwa skor rata-rata pengetahuan responden sesudah diberi penyuluhan adalah antara 76,82 sampai dengan 84,72.

Hasil analisis menggunakan uji paired sample t-test diperoleh skor rata-rata 
pengetahuan responden sebelum penyuluhan kesehatan sebesar 59,23 dengan standar deviasi 15,875 dan sesudah penyuluhan sebesar 80,77 dengan standar deviasi 11,489. Pada hasil uji statistik didapatkan nilai $p$-value $=0,000<\alpha$ 0,05, maka dapat disimpulkan bahwa terdapat perbedaan skor rata-rata pengetahuan sebelum dan sesudah penyuluhan.

Dari uraian diatas secara statistik terbukti ada pengaruh penyuluhan kesehatan terhadap pengetahuan ibu tentang deteksi dini kanker serviks menggunakan metode IVA, dimana skor rata-rata pengetahuan responden sebelum penyuluhan lebih rendah secara bermakna dibandingkan sesudah penyuluhan dengan selisih skor rata-rata sebesar 21,543.

Hasil ini memiliki kesesuaian dengan penelitian yang dilakukan oleh Dewi tentang pengaruh penyuluhan kesehatan terhadap pengetahuan ibu tentang IVA tes di Wilayah Kerja Puskesmas Mantingan Ngawi menunjukkan bahwa rerata skor pengetahuan pretest adalah 71,94 dengan standar deviasi $8,175^{11}$.

Berdasarkan hasil penelitian dan uraian di atas, maka dapat dijelaskan bahwa setelah dilakukan penyuluhan kesehatan tentang deteksi dini kanker serviks menggunakan metode IVA, skor rata-rata pengetahuan responden terjadi peningkatan dengan skor tertinggi adalah 100 terendah 60 dan skor rata-rata yaitu 84,75. Hal ini menunjukkan bahwa menyebarkan pesan melalui penyuluhan dapat merubah pengetahuan individu sehingga perubahan tersebut diharapkan mampu merubah perilaku ibu untuk ikut serta dalam melakukan pemeriksaan IVA.

Hasil penelitian ini sejalan dengan penelitian yang dilakukan Dewi (2012) menunjukkan bahwa terdapat pengaruh penyuluhan kesehatan terhadap pengetahuan tentang IVA tes di Wilayah Kerja Puskesmas Mantingan Ngawi dengan rerata skor pengetahuan pretest adalah 71,94, post-test 78,50 dan nilai signifikansi p-value 0,000.

Penelitian lain juga dilakukan oleh Puspita tentang pengaruh Penyuluhan Terhadap Tingkat Pengetahuan Ibu Tentang Kanker Serviks, Iva Tes Dan Pap Smear Di Puskesmas Jetis Tahun 2014 menunjukkan bahwa pada hasil analisis antara pretest dan posttest menghasilkan nilai signifikansi $\mathrm{p}=0,000(p=0,05)$ artinya terdapat perbedaan yang signifikan mengenai tingkat pengetahuan ibu tentang kanker serviks, IVA tes dan pap smear di Puskesmas Jetis sebelum dan sesudah diberi penyuluhan kesehatan ${ }^{12}$.

Dari uraian-urain diatas dapat dijelaskan bahwa skor pengetahuan ibu tentang deteksi dini kanker serviks menggunakan metode IVA setelah diberi penyuluhan lebih tinggi secara bermakna dibandingkan sebelum diberi penyuluhan. Nilai rerata pengetahuan responden sebelum diberikan penyuluhan sebesar 59,23 
dan rata-rata pengetahuan sesudah dilakukan penyuluhan adalah sebesar 80,77 . Hal ini dapat terjadi karena sebelum diberi penyuluhan, ibu belum banyak mendapatkan informasi secara khusus, langsung dan mendalam yang membahas tentang IVA sehingga pengetahuan yang dimilikinya hanya sebatas dari informasi yang didapatkan melalui keluarga maupun media-media massa. Sesudah dilakukan penyuluhan rerata skor yang didapatkan meningkat sebesar 21,543. Hal ini terjadi karena, penyuluhan sendiri merupakan salah satu bentuk penyebaran informasi secara langsung yang bertujuan agar individu maupun masyarakat secara umum memiliki pengetahuan yang lebih baik sehingga dari penyuluhan tersebut tidak saja sadar, tahu dan mengerti, tetapi juga diharapkan mampu merubah individu untuk berperan aktif dalam mewujudkan derajat kesehatan yang optimal yaitu ikut serta dalam melakukan pemeriksaan IVA sebagai upaya deteksi dini kanker serviks.

Berdasarkan uraian di atas, maka jelaslah bahwa penyuluhan merupakan salah satu metode yang baik dalam mempromosikan program IVA kepada masyarakat khususnya kepada wanita yang berisiko mengalami kanker serviks. Beberapa hal yang perlu diperhatikan dalam memberikan penyuluhan kesehatan agar mendapatkan hasil yang diharapkan diantaranya adalah metode yang digunakan. Metode penyuluhan merupakan salah satu faktor yang mempengaruhi tercapainya suatu hasil penyuluhan secara optimal.

\section{SIMPULAN}

Simpulan penelitian ini adalah pengetahuan ibu tentang IVA sebelum penyuluhan adalah 59,23

Sedangkan pengetahuan ibu tentang IVA sesudah penyuluhan adalah 80 . Hasil uji $t$-test menunjukkan bahwa penyuluhan terbukti efektif meningkatkan pengetahuan tentang deteksi dini menggunakan metode IVA ( $p$-value $=0,000$ $<0,05)$.

\section{SARAN}

Bagi masyarakat khususnya wanita yang sudah/pernah menikah, sering berganti pasangan, wanita yang merokok agar dapat melakukan pemeriksaan IVA. Bagi tenaga kesehatan hendaknya terus berupaya meningkatkan program penyuluhan tentang deteksi dini kanker serviks terutama menggunakan metode IVA

\section{DAFTAR PUSTAKA}

1, World Health Organization, 2015. A month to remember - Breast Cancer Awareness Month. http://www.who.int/cancer/en/

2. Riskesdas, 2013, Riset Kesehatan Daerah tahun 2013.

3. Dinkes , 2015. Profil Kesehatan Provinsi Lampung Tahun 2015 
4. Sabella. F, 2009. Cara Pintar Atasi Kanker. Yogyakarta: Cable Book.

5. Sukaca, 2009. Cara Cerdas Menghadai Kanker Serviks (Leher Rahim). Yogyakarta: Genius Printika.

6. Budiman, 2015. Pencanangan gerakan deteksi dini kanker servik, artikel. www.teraslampung.cora

7. Dinkes Kota Metro, 2015, Profil kesehatan Kota Metro Tahun 2015

8. Notoatmodjo, S, 2011. Kesehatan Masyarakat Ilmu dan Seni. Jakarta: Rineka Cipta

9. Notoatmodjo, S, 2010. Promosi Kesehatan Teori dan Apliaksi. Jakarta: Rineka Cipta
10.Depkes RI, dalam Effendy,2010. Dasardasar keperawatan kesehtan masyarakat.Jakarta.EGC

11.Dewi. Ratna.L 2012, Pengaruh penyuluhan terhadap pengetahuan tentang Iva test diwilayah kerja puskesmas mantengan ngawi. Naskah publikasi, Fakultas kedokteran Universitas 11 maret surakarta.

12.Puspita, dara, 2014, pegaruh penyuluhan terhadap tingkat pengetahuan WUS tentang kanker cerviks,IVA tes dan Pap smear di puskesmas Jetis naskah publikasi. STIKes Aisyiyah Yokyakarta 